\title{
An exploration of the potential for re-distributed manufacturing to contribute to a sustainable, resilient city
}

Freeman, Rachel; McMahon, Christopher Alan; Godfrey, Patrick

Published in:

International Journal of Sustainable Engineering

Link to article, DOI:

10.1080/19397038.2017.1318969

Publication date:

2017

Document Version

Early version, also known as pre-print

Link back to DTU Orbit

Citation (APA):

Freeman, R., McMahon, C. A., \& Godfrey, P. (2017). An exploration of the potential for re-distributed manufacturing to contribute to a sustainable, resilient city. International Journal of Sustainable Engineering, 10(4-5), 260-271. https://doi.org/10.1080/19397038.2017.1318969

\section{General rights}

Copyright and moral rights for the publications made accessible in the public portal are retained by the authors and/or other copyright owners and it is a condition of accessing publications that users recognise and abide by the legal requirements associated with these rights.

- Users may download and print one copy of any publication from the public portal for the purpose of private study or research.

- You may not further distribute the material or use it for any profit-making activity or commercial gain

- You may freely distribute the URL identifying the publication in the public portal 


\title{
An Exploration of the Potential for Re-distributed Manufacturing to Contribute to a Sustainable, Resilient City
}

\author{
Rachel Freeman ${ }^{1}$, Chris McMahon², Patrick Godfrey ${ }^{3}$ \\ ${ }^{1}$ Tyndall Centre for Climate Change Research, University of Manchester, H1 Pariser \\ Building, Sackville Street, Manchester, M13 9PL, UK; \\ rachel.freeman@manchester.ac.uk \\ ${ }^{2}$ Technical University of Denmark, Denmark; chmcm@mek.dtu.dk \\ ${ }^{3}$ University of Bristol, UK; patrick.godfrey@bristol.ac.uk
}

Corresponding author: Rachel Freeman, phone 07786435012

Research conducted at the University of Bristol

This work was carried out as part of the network project Redistributed Manufacturing for the Resilient, Sustainable City (RDM|RSC), funded by the UK's Engineering and Physical Sciences Research Council, grant EP/M01777X/1. The authors would like to sincerely thank all the participants in the RDM|RSC network and especially those that attended our workshops, who came from industry, local government, academia, and community groups - your time, knowledge and interest were invaluable. 


\title{
An Exploration of the Potential for Re-distributed Manufacturing to Contribute to a Sustainable, Resilient City
}

\begin{abstract}
Re-distributed manufacturing (RDM), broadly described as manufacturing done at a smaller-scale and locally, could be beneficial to business and urban society through creating jobs, reducing the environmental impacts of production, and improving resilience to future disturbances. Consideration of RDM within a city-region requires the consideration of a wide range of issues societal, technical, economic, and environmental. This paper presents the results of a study into the potential for RDM to contribute to a sustainable, resilient city in the face of a range of expected future disturbances on the city and on manufacturing sectors. The study took an integrated assessment approach which incorporated the development of a conceptual framework; a "strawman” causal loop diagram which was reviewed by participants in a workshop; and a stock and flow system dynamics model that represents our understanding about the structure and behaviour of urban manufacturing. Several key themes emerged: similarities between RDM and traditional manufacturing, availability of physical space for RDM to be done, achieving urban resilience through RDM by enabling responsiveness to disturbances, changes in environmental impacts from production, additions or losses in jobs, the competitiveness of local manufacturing, and skills and innovation for RDM technologies. Further work is recommended.
\end{abstract}

Keywords: Sustainable manufacture; Sustainable technology innovation; Green supply chains; Sustainable business models; Resilience; Re-distributed manufacturing

\section{Introduction}

This paper presents the results of a study into the potential impact of moves towards redistributed manufacturing (RDM) in an urban environment, with a focus on the possible role of RDM in improving the resilience and sustainability of one particular city - Bristol, UK - and its region. The study used the method of integrated assessment to bring structure to a broad research agenda. Key outputs from the study include a 
conceptual framework and a system dynamics model which represents our findings about the behaviour of the system of interest. Creation of these outputs was informed by a wide variety of data including a review of the literature and a series of workshops with a range of experts. The study has contributed a new viewpoint about this emerging subject and an approach for exploring the issue of redistributed manufacturing and its role in society. The study identified seven key themes that are likely to be important for the success of RDM in future. We envisage that the system dynamics model could be used as a decision support tool, helping policy makers and others working in this field to consider the interrelationships between sustainability, resilience and manufacturing in the light of future disturbances.

RDM can be broadly described as manufacturing done at a smaller-scale and locally, often using new production technologies - as compared to mass manufacturing done in centralised locations with products delivered through distribution networks. RDM could be locally made for local sale, or locally made for sales outside the region. RDM has been described as epitomising an on-demand economy, with local manufactories "reshaping and redefining markets and supply chains, requiring new decentralised business models and having wide ranging challenges and implications” (Pearson, Noble, and Hawkins 2013). The RDM agenda is largely based on the growing availability of new technologies, such as computer-enabled additive layer manufacturing, which enable small-scale production of artefacts that in the past would have required a large capital investment in production plant.

The interest in RDM arises from its potential benefits for industry and for society as a whole. Some of these potential benefits include an improvement in the productivity of manufacturing; a reduction in the environmental impacts of manufacturing; enabling the use of new materials, or existing materials to be used in a 
new way; reducing a region’s dependence on global supply networks; creation of new jobs for semi-skilled workers; and improvements in the economic sustainability of a region through increased diversity of economic activity.

\section{Terminology}

We first define the key terms used in the study.

“Manufacturing” as a classification of economic activity can include a range of activities associated with the supply of physical artefacts including research, design and development, production, logistics and distribution, in-life service or remanufacturing, and end of life take back. For this study we take "manufacturing" to be the creation (or repair, or remanufacture) of any tangible artefacts from raw materials and/or parts; we do not include construction of infrastructure, utilities, engineering design when not connected with production, software, mining, and agriculture.

Redistributed Manufacturing has been defined as: “Technology, systems and strategies that change the economics and organisation of manufacturing, particularly with regard to location and scale” (Pearson, Noble, and Hawkins 2013). For this study we take RDM to be the localisation of the design and production of manufactured artefacts, especially through the use of small-scale and innovative production methods and associated business models, which has the potential to benefit a region's economy, society and environment, and to improve its resilience to future megatrends such as climate change and globalisation of supply networks. Under the umbrella of RDM there could arise: new business models, new or updated manufacturing technologies, new skills, use of new materials and locally sourced materials, and the application of traditional making skills in a new way.

“Sustainable" means that a system can continue to function over an indefinite period of time. When applied to cities the concept is best defined deductively rather 
than inductively (Höjer and Wangel 2015). Sustainability indicators can cover a range of environmental, social, and ethical concerns (Alusi et al. 2011). The development of urban sustainability indicators can be informed by urban metabolism studies ((Kennedy, Pincetl, and Bunje 2011); Inostroza 2014). Urban metabolic rates describe energy and material flows into and out of a city or region and accumulations of materials (Hendriks et al. 2000). Zhang (2013) finds that in general "large metabolic throughput, low metabolic efficiency, and disordered metabolic processes are a major cause of unhealthy urban systems”. For this study we take the term "sustainable” to mean the city has healthy ecosystems, and it can maintain a low urban metabolism that is decoupled from economic growth while improving societal well-being.

“Resilience” is a rather broad concept. Hosseini et al. (2016) reviewed a range of definitions and measures of system resilience in the literature, identifying four domains of resilience - organisational, social, economic, and engineering. Concepts used in relation to resilience include "anti-fragility” (Taleb 2012) and "robustness, faulttolerance, flexibility, survivability, and agility” (Hosseini, Barker, and RamirezMarquez 2016). Vugrin et al. (2011) describe resilience as a function of absorptive capacity (ability to absorb shocks from a disruption), adaptive capacity (ability to adapt temporarily to new and disrupted conditions), and restorative capacity (ability of a system to restore itself if adaptive capacity is not effective). For this study we take the term "resilient", in relation to a city, as its ability to maintain infrastructure and to thrive environmentally, economically and socially in the face of a range of short and long-term disturbances.

“Disturbances" is taken to mean those short-term shocks (e.g. lasting from a few hours to a few weeks) and long-term stressors (which build up over months or years) that can affect a city-region and its manufacturing sectors. Disturbances can 
come from within the region (e.g. social unrest, industrial accidents) or from outside the region (e.g. climate change, global recession).

\section{Methodology}

Since this study takes a regional perspective there is a need to consider a wide range of technical and social issues in relation to each other across a highly heterogeneous space. Integrated Assessment (IA) is a method that has been used to carry out comprehensive assessments at the societal level of, amongst many other subjects, the impact of climate change on urban areas (Dawson et al. 2014). IA has been described as an interdisciplinary process of “integrating knowledge from various disciplines and stakeholder groups in order to evaluate a problem situation from different perspectives” (Pahl-Wostl 2004). The IA approach is comprehensive and systemic and includes information about the needs and concerns of communities and industry, as well as knowledge about the environment (Hutchinson et al. 2006). In relation to cities, IA enables urban planning researchers to "re-frame the questions that are asked so as to link global, regional and local scales and their interactions in the context of future urban planning” (Dawson et al. 2014).

Whilst a full IA is out of the scope of this study, we use the principles of IA to bring structure to what could be a rather unwieldy research agenda. The IA structure that was used describes eleven steps, as defined in (Hutchinson et al. 2006) and outlined in Table 1. Only the first five steps were done in this study.

\section{TABLE 1 HERE}




\section{Modelling}

Two models were created during this study. Data that informed the creation of the models came from a literature review, reviews of local manufacturing history, and notes from a series of workshops with diverse groups of experts. The second model was a revision and extension of the first model, informed by feedback from workshop participants. Both models were created using methods from the field of system dynamics (Forrester 1991; Richardson 2011).

The first model (Figure 2) was developed using the method of causal loop diagramming. Causal loop diagrams (CLDs) are "visual representations of the dynamic influences and inter-relationships that exist among a collection of variables” (Spector et al. 2001). CLDs can quickly capture hypotheses about the causes of the dynamics of a system, representing the combined mental models of individuals or teams who have knowledge about the system and communicating the important feedbacks within the system (Sterman 2001). CLDs use the following nomenclature: positive causation (as A increases or decreases then so does B) is represented by arrows with a "+” sign; negative causation is represented by arrows with a “-_" sign (as A increases or decreases, B decreases or increases); balancing loops represent goal seeking or growth limiting feedback; reinforcing loops represent feedback loops that lead to growth.

The second model (Figure 3) was developed using stock and flow modelling, a format that describes the physical structure of a system of interest. System dynamics theory proposes that the behaviour of a system arises from its structure-consisting of reinforcing and balancing feedback loops, stocks, and flows— and from the nonlinearities that are created when the decision-making processes of agents within a system interact with the system structure (Sterman 2000). Models are composed of three main types of elements: stocks represent accumulations of things that influence system behaviour and change slowly; rates define the rate at which processes in the model 
move things into or out of the stocks; auxiliaries can be defined as constants (e.g. exogenous influences on the system), or as variables (calculated with equations that take values from other stocks or auxiliaries). Due to time constraints, the model presented in Figure 3 has not been parameterised, but it provides a basic structure that could be developed further in future research.

The following five sections describe the IA steps that were carried out, with the description of each step given in the section title (based on the methodology given in [Hutchinson et al. 2006]).

\section{IA Step One - Identify the aims and objectives of the integrated assessment, including stakeholders and potential audiences for the results}

The aim for the IA is to explore, in a comprehensive and theoretically well-founded way, the dynamical relationships between a city's resilience and sustainability and its manufacturing sectors, and the potential role that RDM could play in these relationships in future.

The objectives for the IA are as follows: review existing knowledge on the key concepts of the study; establish a conceptual framework to guide the research; create a high-level model of the basic relationships between the key concepts; draw out insights from the model into the potential role for RDM in improving the resilience and sustainability of a region; and make recommendations for future work.

The key stakeholders are: the funding body (the UK’s Engineering and Physical Sciences Research Council (www.epsrc.co.uk)), local citizens, local government, social enterprises, and businesses in the Bristol region. Other potential audiences include: citizens in other cities, UK central government, those in the research community that are working on sustainable manufacturing and resilience issues, and international investors. 


\section{IA Step Two - Build an understanding of the constraints and issues in the case study as well as possible measures of system performance}

Identified constraints for the study include the limited project timeline, the need to consider a wide range of subjects in relation to each other, the need to consider a landscape with high heterogeneity, and the unavailability of detailed data on regional manufacturing activities.

\section{Issues Described in Existing Literature}

A review of existing literature reveals some of the links between the key themes of the study - cities, resilience, sustainability and manufacturing.

At the city level Asprone et al. (2014) describe the resilience of a city as being the combined economic, social and environmental sustainability of the city within different phases of its lifecycle, with extreme events causing cities to move to new phases - described as points of dynamic equilibrium. Developing resilience capacity for a city will require research that is more trans- and inter-disciplinary, in order to learn what makes "knowledge about nature-society interactions useful within both science and society” (Ahern 2011). For example, decision makers can holistically view the design of goods and services and regions through examination of material flows, leading to improved sustainable development and early recognition of resource or environmental problems (Barles 2009).

Eco-efficiency - “improvements in resource efficiency at the resolution scale of individuals, firms and even small communities” (Frye-Levine 2012) - is usually a key part of sustainability strategy for state and local governments and businesses. At the level of a region, eco-efficiency can be described as "the efficiency with which ecological resources are used to meet human needs” (J. Huang et al. 2014). An emphasis on eco-efficiency, however, could prove to be counter-productive when it 
comes to improving the resilience of organisations, and a strategy of "adaptation, transformation and evolution” (Korhonen and Seager 2008) will be more likely to succeed - even if actions appear to be inefficient.

Considering sustainability in manufacturing, Rauch et al. (2015) identify four key elements: economy (cost of energy and materials), ecology (rate of use of resources), social (workplace welfare, skill levels), and political-institutional (public funding for sustainable manufacturing). Resilience for manufacturing organisations depends on their ability to be flexible - redeploying their resources effectively in response to changing conditions - and on financially evaluating advanced manufacturing technologies in a way that is not based solely on standard economic criteria (Mohanty and Deshmukh 1999). While many organisations seek improvements in efficiency through "lean” supply chain solutions, to achieve resilience organisations need to be flexible and agile, for example through establishing collaborative supply chain relationships based on transparency of key information (Christopher and Peck 2008). A study by Thomas et al. (2016) found that manufacturing companies that are better at applying resiliency and business sustainability models - for example, Six Sigma, quality management, lean, fit manufacture, knowledge management - are generally more economically sustainable and resilient.

Regarding the potential role of RDM, the UK's Foresight committee see responsive RDM and urban-based manufacturing as forming a part of the future production landscape, with more urban manufacturing and responsive "reconfigurable units integrated with the fluid requirements of their supply chain partners” (Foresight 2013). Kohtala’s (2015) wide ranging review of the literature on sustainability in distributed production conceptualised the distributed production landscape as: bespoke fabrication, personal fabrication, mass customisation and mass fabrication - each with 
its own potential environmental benefits and concerns. Whilst there are indications that greater environmental sustainability could be achieved through distributed production, there is no certainty that it will lead to a new and clearly cleaner manufacturing paradigm (Kohtala 2015). Rauch et al. (2016) find that while the concept of distributed manufacturing systems could play a major role in enabling sustainability in manufacturing, it cannot be applied within every industrial sector and for every product.

Small and medium sized enterprises (SMEs) could especially benefit from RDM technologies, increasing automation and the ability to customise solutions for their customers, while minimising environmental impacts by locating technology, people and materials close to markets (Ball and Jolly 2015). The most commonly discussed manufacturing technique in RDM is additive layer manufacturing, which enables sustainability to be improved within the processes of "product and process redesign; material input processing; make-to-order component and product processing; and closing the loop” (Ford and Despeisse 2015). Fox (2015) proposes that a practical solution for increasing RDM could be moveable factories which can enable local people to carry out sustainable manufacturing even where there is a lack of supportive infrastructure and manufacturing skills.

\section{The History of Manufacturing in Bristol}

In this section we summarise key points from a review of local historical reports and a “maker walk” exercise conducted by others in the RDM research network to map Bristol’s manufacturing landscape. Bristol has a long history of manufacturing enterprise, with manufacturing providing up to a third of local employment throughout a large part of its 800 year history. The 1800s saw growth in manufacturing in the city, with a wide range of materials and goods being made including glass, shot and bullets, shoes, motorcycles, chocolate, and tobacco products. Manufacturing growth was 
supported through new infrastructure such as the "floating harbour" and an airstrip to the north of the city. By the 1980's, much of the mass manufacturing was gone due to a combination of mega-trends such as mergers and acquisitions, rising salaries, low-cost production in other countries, and the declining cost of consumer goods.

More recently, high-value manufacturing in aerospace and electronics has grown in the region, with these industries providing a good income stream for the city but less than $10 \%$ of its employment. Some manufacturing companies have survived by sending production to lower-cost countries but retaining their product design and corporate headquarters locally - with the resultant loss of semi-skilled jobs. There are some smaller manufacturing companies still producing locally that are not part of the high value sector, however. These producers have one or more of several key characteristics: their products are not worth shipping long distances since they are needed quickly and are customised (e.g. parts for the building trade); the products are bulky and relatively inexpensive, meaning shipping is not worth it; the businesses are locally owned and committed to staying in the area; products are unique to the area or are niche (e.g. specialist clothing for fire-fighters); productivity has been sufficiently improved with new manufacturing techniques to make the products competitive.

\section{Measures of System Performance}

The terms “resilience” and “sustainability” are key measures of system performance, since the study is seeking to understand if they could be improved through RDM. These terms need to be broken down, however, since they have different meanings at different scales of space and time. Table 2 presents five key measures of system performance, based on a review of literature and discussions within the project team. An ideal scenario would be that all of these measures of system performance are synergistic and show improvement over time. Then manufacturing sectors would contribute positively 
to the four sustainability and resilience measures, economic sustainability would support environmental sustainability and resilience, and the city’s resilience and sustainability strategies would support the resilience of local manufacturing.

TABLE 2 HERE

Step Three - develop an initial conceptual framework, including key drivers, management and development options, and state and utility variables and their interactions

This step began with the project team carrying out a STEEPLE analysis (Social, Technical, Economic, Environmental, Political, Legal, and Ethical) related to the research themes. This was based on the team's knowledge; three internal network meetings; three workshops with around 30 attendees from a variety of backgrounds including local government, industry, and academia; local and national risk registers; and the literature review done in Step Two. Key elements are presented in Table 3 as drivers, management and development options, and state and utility variables. Note: this is by no means an exhaustive list.

\section{TABLE 3 HERE}

\section{Conceptual Framework}

An initial conceptual framework was developed based partly on the Press-Pulse Dynamics framework from Collins et al. (2011), which sets disturbances in context, in relation to an ecosystem and the human systems that live within it; it defines a "press" as a long-term stressor, such as sea level rise, and a "pulse” as a discrete event that rapidly alters ecosystem function. While Collins et al.'s framework is designed to enable discussion of human-ecosystem interactions, we have applied it to the discussion 
of the overall environment in which manufacturing operates. Thus, we interpret presses as long-term drivers and pulses as short-term drivers. The Pulse-Press Dynamics framework uses the terms "structure" and "function", which are used in the field of ecology to differentiate between the core components of an ecosystem and the suite of processes that occur within the ecosystem (Grimm et al. 2008). We use these terms to distinguish the structural (e.g. infrastructure) elements of the manufacturing and economic/social systems from the functional ones.

Figure 1 presents the conceptual framework. On the right, the local manufacturing template includes the structures that enable manufacturing, and the ongoing functions carried out by manufacturers. In the middle, the manufacturing environment incorporates the local biophysical environment and social/economic systems. On the left are the key pulses and presses.

FIGURE 1 HERE

Five integrating hypotheses are represented as arrows in the diagram. These hypotheses are propositions about what types of processes link the different parts of the framework.

H1: Pulses and presses from inside or outside the local environment can affect both the structure of the local environment and its functions. The more resilient and sustainable the local environment is, the more likely it can continue to function despite disturbances.

H2: Structure and functions in the manufacturing sectors are dependent on and influenced by the local environment, including the biophysical structure and economic/social functions such as infrastructure services and transport networks. 
H3: The activities of manufacturers and the structures developed to support manufacturing activity, affect the local environment through adding to the tax base, creating social capital, creating emissions, etc.

H4: The way the local environment is managed and activities are carried out can impact the severity or likelihood of local pulse events. For example, good environmental management can prevent industrial accidents and environmental pollution.

H5: Pulses and presses affect local manufacturers directly through impacts such as global competition, technology disruption, demographic changes, and worldwide commodity markets.

We can relate the history of Bristol manufacturing to the conceptual framework. For example, the mega-trends that decimated Bristol's mass manufacturing are represented in H5; one secondary effect of this was high unemployment in some wards of the city, as represented in H3; a second secondary effect has been the loss of structure in the manufacturing template as buildings once used for manufacturing are repurposed as residential accommodation, hotels or offices.

\section{IA Step Four - Workshop the initial conceptual framework and general scenarios with stakeholders}

A “strawman” Causal Loop Diagram (CLD) was developed by the project team (Figure 2), based on the conceptual framework, with the intention to stimulate debate about the causal influences on the measures of system performance. The process of building the strawman included the following steps, which were done by the project team: (i) decide on the purpose of the model - i.e. to conceptually represent our understanding about the dynamic relationships between the four key themes of the research (sustainability, resilience, manufacturing, cities); (ii) identify a small set of system elements to include 
in the CLD, based on the identified measures of system performance (Table 2) and any other variables needed to make sense of the model such as the manufacturing industry and disturbances; (iii) relate the system elements together in a causal way, based on the conceptual framework, a literature review, and the findings of preliminary workshops; (iv) present initial versions of the model to colleagues to get feedback on its understandability and relevance; (v) revise the CLD until it is relatively easy to explain and justify to people from a range of different backgrounds (e.g. engineering, economics, social sciences).

Whilst the CLD in Figure 2 differs from the conceptual framework in Figure 1, which has integrating hypotheses as opposed to causal links, there are some obvious links between the two: H1 (disturbances affect the local environment) and H5 (disturbances affect the manufacturing sector) are represented by causal arrows from the exogenous elements named "presses (megatrends)” and "pulses (short-term disturbances)” which are shown impacting the city-region resilience and sustainability feedback loops (right hand side of the model) and the manufacturing sector feedback loops (left hand side of the model); H2 (local environment affects manufacturing sector) is represented as the causal link between "impact on city-region" and "manufacturing sector health”; H3 (manufacturing sector impacts local environment) and H4 (environment influences disturbances) were not directly represented in the CLD since there was too much uncertainty about the size and direction of causation.

FIGURE 2 HERE

The strawman model was presented to five groups of participants in a workshop. Each group was made up of five to eight people, with a rapporteur taking notes and leading the model review. Workshop participants were members of the project's network from a 
variety of backgrounds including academia, manufacturing, social enterprises, local government, and private citizens. The workshop groups came up with a wide variety of additions and changes to the models, and several themes emerged during a concluding general discussion, as discussed in the next section.

\section{IA Step Five - Revise the initial framework using stakeholder feedback, producing a working version of the conceptual framework}

Table 4 presents a summary of comments on the strawman model made by the groups in the workshop, along with reflections from the project team.

\section{TABLE 4 HERE}

\section{Revised conceptual framework}

This section presents a revised version of the conceptual framework as a system dynamics stock and flow model (Figure 3). The inputs to this version were the conceptual framework hypotheses (Figure 1), the strawman CLD (Figure 2), feedback on the strawman CLD from workshop participants (Table 3), a review of Bristol's manufacturing history by the project team ${ }^{1}$, the results from the "maker walk", discussions with local historians, and other literature on Bristol including (Harvey and Press 1988). The revised model represents our understanding of broad historical trends in Bristol in relation to the measures of system performance, and is useful for exploring what trends may happen in the future.

\footnotetext{
${ }^{1}$ Two reports were written by James Throup: “The History of Tobacco Manufacture in Bristol”, and “Aerospace Manufacturing in Bristol”, published at www.rdmrsc.org.uk/resources/resource-items/
} 


\section{Model Explanation - Stocks}

The model is presented as a starting point for discussion. It is a model of our understanding about a problem rather than a model of a system - the problem being the desire to understand the potential for RDM in a city’s future. The model has six stocks, described as follows:

Manufacturing sector capital - assets of manufacturing companies, including production machinery, intellectual property, company reputation, buildings, and specialist expertise and knowledge.

Manufacturing activities - total volume of production, design and support work related to manufacturing.

City infrastructure - civic infrastructure including the port, bridges and roads, public buildings, railways, and services infrastructure (water, gas, sanitation, telecommunications)

Local economy - private and public activities including running of the local government, provision of public services such as health, fire and police services; and operations of private companies (not including manufacturing)

Local environment health - the biodiversity, water management, and air quality in the region, including productivity of agriculture and green spaces for recreation

Combined, accumulated active disturbances - the total impact from a wide range of disturbances that come and go over time. Disturbances can occur singularly or in combination, may be larger or smaller in impact, and may last for a short or long time (the range of known possible disturbances is given in Table 2: Key drivers, management and development options, and state and utility variables); disturbances either eventually cease (e.g. high rainfalls stop), or become the new normal (e.g. mass manufacturing is lost and buildings repurposed). Since modelling the individual effect of a combination 
of pulses and presses would require a very complex model, and since little is known about the possible patterns of these disturbances, these are presented as a single stock. As disturbances arrive, the implications for the city change in terms of coping or adapting. For example, a local, short disturbance such as an accident that causes a major road to be closed can be dealt with within a few hours by local police, but if this happens daily the damage would accumulate. Similarly, if a smaller press lasts for a long time, it can have a large impact. For example, the winter of 2013/2014 saw the highest rainfall in 200 years in the UK over a two-month period, which caused flooding in many places - but there were few days in which rainfall was extreme. The model considers disturbances as exogenous impacts on the city, with shown as arrows coming from the disturbances stock and impacting environment, infrastructure, economy, and manufacturing. The assumption is that disturbances will be damaging; however, some businesses may be able to create opportunities out of disturbances such as technology change, through being innovative and gaining market share.

\section{Model Explanation - Causal Loops}

In system dynamics models stock levels change through causal connections that influence the flows connected to the stocks. We examine causation in the model through highlighting the main feedback loops between stocks, flows and auxiliary variables. The descriptions of feedback loops constitute our hypothesis about the dynamics of the system of interest. They are not stating that "this has definitely happened" but "this is our understanding of what has happened in relation to the problem we are interested in”. Theory on the feedback loops is presented in the order that the loops are shown in Figure 3, from right to left.

R1: as manufacturing activity grows it supports the creation of more manufacturing capital, and this capital in turn supports ongoing manufacturing activity. 
During much of the $18^{\text {th }}$ and $19^{\text {th }}$ centuries, and the first part of the $20^{\text {th }}$ century this loop led to the creation of a large amount of physical manufacturing capital such as factory buildings and machinery. During the latter part of the $20^{\text {th }}$ century, the creation of capital shifted towards the creation of "knowledge capital" in high-value industries such as electronics and aerospace.

R2: the more manufacturing activity, the more manufacturing clusters and diversity, which leads to both skills and technology innovation, and overall manufacturing resilience; resilience, especially provided by diversity, reduces the impact of disturbances. This loop has been dominant for different industries at different times, such as during the growth of the aerospace industry that started in the first half of the $20^{\text {th }}$ century.

R3: societal resilience supports the generation of continual local ownership and leadership, which in turn supports more societal resilience.

R4: manufacturing activities provide a range of jobs, which improve societal resilience, which supports local ownership and leadership, which improves manufacturing sector resilience (e.g. reducing the risk of takeovers), which reduces impacts from disturbances on manufacturing activities.

R5: a lack of manufacturing activity spurs the creation of non-manufacturing activities (after some delay and supported by societal resilience), which puts pressure on manufacturing spaces to be converted to other uses, limiting or even reducing manufacturing capital and hampering manufacturing start-ups who need relatively cheap spaces to rent. This loop runs counter to the other reinforcing loops and has been a strong trend in Bristol since the 1980s.

B1: impacts on manufacturing from disturbances, combined with fixed constraints from regional geography and climate, provide an impetus for innovation, 
which improves manufacturing sector resilience, which reduces impacts; this loop balances in response to disturbances. In some cases, this could increase manufacturing competitiveness compared to other cities.

R6: provision of infrastructure supports growth of the local economy, which allows building of new infrastructure, adding to the total stock of infrastructure.

R7: local economy (especially regarding local government budgets) supports investment in maintenance and robustness of infrastructure, which reduces the impacts of disturbances on infrastructure. When impacts are stronger than infrastructure robustness, this loop reduces infrastructure and economy.

B2: local economy creates environmental impacts such as air pollution, which combine with disturbances that impact environment but are reduced by legislation such as environmental protection regulation; impacts reduce environment health, which leads to a reduction in the robustness of city infrastructure through issues such as flooding; this balancing loop could limit the economy when disturbances are large.

Note: There are several other feedback loops that can be identified in the model; we have highlighted here only the major ones.

FIGURE 3 HERE (LANDSCAPE)

\section{Implications for RDM}

In terms of RDM playing a role in a future sustainable and resilient city, there are three considerations: (i) How much RDM could thrive within the city as it exists now, (ii) How much RDM might thrive in the face of strong future disturbances, and (iii) How well the outcomes of more RDM might align with the goals of regional sustainability and resilience. 
Figure 3 allows us to consider these questions in context. The consideration has been done in a broad sense by looking at the stocks, flows, causal loops and exogenous variables, and by considering the differences between traditional manufacturing and RDM in the context of a city-region. The comments that follow are in no way a prediction but are an exploration of these considerations within what could be a rather uncertain future compared to the past. There are seven key points to consider.

Similarities: RDM activities would likely be supported by the same conditions that have supported traditional manufacturing, as indicated in the model - including a diverse sector, manufacturing clusters, skills and technology innovation, local ownership and leadership, and investment in building and maintaining civil infrastructure.

Physical Space: Based on the definition of RDM as being "small scale”, it is likely that RDM will in general require smaller physical spaces than traditional mass manufacturing, so in some sectors (e.g. the 'maker' community) the tie-in to physical manufacturing capital could be less important than in the past (R1). However, production still needs some physical space and because of R5 there is now less opportunity for RDM start-ups who need affordable space where manufacturing is permitted. This potential dampener for the growth of RDM was highlighted by several people running start-ups during a "maker walk" mapping of local manufacturing by the project team.

Resilience through Responsiveness: In theory, RDM activities, and especially those that utilise the latest technologies, should be more agile and able to respond positively to disturbances such as changing global markets or changing availability of material resources. This is because design and production could be done with a much 
quicker turn around, and customisation will be easier and cheaper to carry out. This would make balancing loop B1 stronger.

Environmental Impacts: Products made through RDM could be less environmentally impactful than products with a long supply chain, especially if made "local for local". There are several caveats to this idea, however. Firstly, there needs to be sufficient and appropriate environmental regulation, and this is more difficult to implement when production is small-scale and distributed. Secondly, there is a lack of evidence on whether RDM processes are more or less energy and material efficient than mass manufacturing (S. H. Huang et al. 2013); this could be quite different depending on the product, its material construction, and its lifetime use. Thirdly, environmental impacts are highly dependent on product design; an emphasis on circular economy, repair, and recycling in combination with RDM technologies could provide a large environmental benefit but some current RDM technologies produce products that are not recyclable or repairable. Thus, B2 may be stronger but only if regulation, production, and design are done with this in mind.

Additions and Losses in Jobs: RDM has been proposed as a way to bring back some of the semi-skilled jobs that have been lost through offshoring (R4), but this outcome is rather uncertain; most of the existing RDM appears to create predominantly highly skilled or very niche jobs and so its contribution to reducing inequality may be less than traditional manufacturing. It's possible that creating semi-skilled jobs would require different business models or public support. In terms of job losses, it is unlikely that manufacturing of large, complex products such as aeroplanes will be impacted very much by RDM. Local parts manufacturers could use RDM to shorten supply chains and so create more local business and jobs; on the other hand, large companies could use 
RDM to make their own parts instead of buying in parts from suppliers, meaning a loss of jobs in SMEs.

Competitiveness: It is unlikely that RDM products could compete with cheap mass produced products from low-cost countries, unless supply chain disturbances cause a significant drop in availability of imported goods (and in this case imported materials would also be impacted), or RDM technology improves so much that it can make a surprisingly large downward impact on production costs. Regarding "local for local” production there is unlikely to be high volumes of low-value goods made and sold. RDM could, however, increase competitiveness of high-value and niche goods made for local or global markets.

Skills and Innovation: Technology innovation within SMEs who wish to do RDM could be more difficult to achieve than within traditional manufacturing, since smaller companies have fewer investment resources for research and development. This would increase the importance of manufacturing clusters, academic and government support for technology innovation, and skills training for RDM technologies.

Infrastructure: Many of the services that manufacturing uses are supplied through urban infrastructure, and innovation in infrastructure can even stimulate innovation in manufacturing (Luger, Butler, and Winch 2013). The historical interdependence between infrastructure and manufacturing is represented in Figure 3 by a larger and more slow-moving feedback, described as follows: As the stock of city infrastructure grows, this supports increases in the stock of manufacturing sector capital, which ties into manufacturing activities through R1; manufacturing activities create jobs and increase societal resilience, reducing the impacts on the local economy from disturbances and so supporting investment in infrastructure. Whether this feedback will continue to exist in the UK while the services sector dominates economic activity is 
uncertain. However, at the time of writing the UK government has published a new industrial strategy ${ }^{2}$ that includes investment in "manufacturing processes and materials of the future” - hopefully some of this investment can stimulate RDM in urban areas.

\section{Conclusions}

The research described in this article has developed a new viewpoint on the relationship between the resilience and sustainability of city-regions and their manufacturing sectors. The creation of a conceptual framework, creation of a causal loop diagram and review through a workshop, and building of stock and flow diagram allowed an exploration of the past role of manufacturing in city resilience and sustainability, and the potential role of RDM considering a range of future potential disturbances.

Manufacturing has been a vital part of the development of the city of Bristol over the centuries of its history but its nature and importance has changed in recent decades, moving from mass manufacturing to predominantly high-value manufacturing and local niche manufacturing. In considering possible growth in RDM in future, the study found that several factors are likely to be important including training in RDM technology skills, support from the public sector in research and development, investment in local infrastructure, local ownership and leadership, and the availability of affordable and suitable manufacturing space in the city for start-ups and SMEs to operate in.

The model presented in this paper represents our understanding about the interdependencies between environment, infrastructure, social resilience, and manufacturing sectors, and the impact of disturbances. We use it to consider the

\footnotetext{
${ }^{2}$ https://beisgovuk.citizenspace.com/strategy/industrialstrategy/supporting_documents/buildingourindustrialstrategygreenpaper.pdf
} 
potential impacts of an increase in RDM in future, in which there is expected to be an increase in the size and frequency of a range of short and long-term disturbances. These disturbances will affect both the city and its manufacturing sectors - either directly through interaction with global and local markets, or indirectly through loss of services or infrastructure.

Several key feedback loops were identified and described in the model, which have come into play during different periods in the city's past and which could be important for RDM in future. RDM could strengthen or weaken the feedback loops depending on how it is developed. For example, there could be both good and bad impacts on the local employment market with more jobs for semi-skilled workers, but only if this is supported by corresponding business models. There could be reduced lifecycle environmental impacts for products consumed in the city, but with more of those impacts occurring within the city compared to when most production is offshored. RDM technologies have been promoted as more energy and material efficient, but this is not always the case; reducing lifecycle impacts depends on the design, production and regulation being done with this in mind.

In the light of a range of possible future disturbances, RDM may prove to be more agile and resilient than traditional manufacturing, depending on what kind and strength of disturbances occur in the future and on what kind of support is provided from government and academia to develop technology and related business models. In terms of the size of the potential overall impact from RDM on the local economy and the resilience of the city, unless there is a very large disturbance to global supply chains in future, or a significant change in product design towards repair and reuse, it is likely that the impact will be small relative to the city's currently dominant economic sector of services. 
In terms of research methodology, the approach developed in this study has been provided a process for exploring a wide-ranging and complex manufacturing issue. Causal loop diagramming proved to be a useful approach for an initial exploration of the key relationships in the research agenda and stimulating people in the research network to think about interrelationships between the main themes of the research, rather than single issues related to manufacturing. The merging of workshop findings, a literature review, and other data to create a representative stock and flow model allowed for the creation of a more formal theory about the structure of the system of interest and the research questions in the research theme. Time limits did not allow the model to be parameterised, and so its usefulness is limited to conceptualising stocks, flows and feedback loops rather than gaining understanding about system behaviour over time.

\section{Further Work}

Further work on this subject could include the development of the system dynamics model to be simulatable. This would require incorporating findings from a wide range of reports and carrying out data analysis to reveal historical trends. A simulatable model could be used to test various "what if” scenarios for different types of RDM in the future in the face of different levels and type of disturbances, leading to a new understanding of the size and timing of effects of disturbances on manufacturing and the city.

Another approach would be to combine the system dynamics model with an event-based modelling method. For example, Schieretz and Grossler (2003) combined system dynamics with agent-based modelling to examine supply chain structures. The combined continuous model and event-based model could better represent the impacts of disturbances on a functioning system. Another option would be to create an agentbased model to envisage how RDM could grow through the actions of different actors 
in the city, since much of the potential for RDM is likely to be actualised by innovative businesses of different sizes and types. Any further work done in relation to this study would benefit from continuing with the structure of the IA.

\section{Acknowledgements}

This work was carried out as part of the network project Redistributed Manufacturing for the Resilient, Sustainable City (RDM|RSC), funded by the UK's Engineering and Physical Sciences Research Council, grant EP/M01777X/1. The authors would like to sincerely thank all the participants in the RDM|RSC network and especially those that attended our workshops, who came from industry, local government, academia, and community groups - their time, knowledge and interest were invaluable.

\section{References}

Ahern, Jack. 2011. "From Fail-Safe to Safe-to-Fail: Sustainability and Resilience in the New Urban World.” Landscape and Urban Planning 100 (4). Elsevier B.V.: 34143. doi:10.1016/j.landurbplan.2011.02.021.

Alusi, Annissa, Robert G Eccles, Amy C Edmondson, and Tiona Zuzul. 2011.

“Sustainable Cities: Oxymoron or the Shape of the Future?” Harvard Business School Organizational Behavior Unit Working Papers; Volume 11, Issue 62, Edition 3.

Asprone, D., A. Prota, and G. Manfredi. 2014. "Linking Sustainability and Resilience of Future Cities.” In Resilience and Sustainability in Relation to Natural Disasters: A Challenge for Future Cities, edited by Paolo Gasparini, Gaetano Manfredi, and Domenico Asprone, 55-65. Cham, Switzerland: Springer International Publishing. doi:10.1007/978-3-319-04316-6_5.

Avon and Somerset Local Resilience Forum. 2014. “Community Risk Register, Version 
5.0.” http://www.somerset.gov.uk/policies-and-plans/plans/preparing-foremergencies/.

Ball, Peter, and Mark Jolly. 2015. "Sustainable Manufacturing for the Future: Investigating the Current and Future Landscape across the Food and Drink Industry in Great Britain.” Cranfield University; Coca-Cola Enterprises Great Britain.

Barles, Sabine. 2009. “Urban Metabolism of Paris and Its Region.” Journal of Industrial Ecology 13 (6): 898-913. doi:10.1111/j.1530-9290.2009.00169.x.

Christopher, Martin, and Helen Peck. 2008. "Building the Resilient Supply Chain.” International Journal of Logistics Management 15 (2): 1-13. doi:10.1108/09574090410700275.

Collins, Scott L., Stephen R. Carpenter, Scott M. Swinton, Daniel E. Orenstein, Daniel L. Childers, Ted L. Gragson, Nancy B. Grimm, et al. 2011. “An Integrated Conceptual Framework for Long-Term Social-Ecological Research.” Frontiers in Ecology and the Environment 9 (6): 351-57. doi:10.1890/100068.

Cooke, Philip. 2012. Complex Adaptive Innovation Systems. Abingdon, UK: Routledge. Dawson, Richard, Annemie Wyckmans, Oliver Eidrich, Jonathon Kohler, Stephen Dobson, and Efren Feliu. 2014. Understanding Cities: Advances in Integrated Assessment of Urban Sustainability. Final Report of COST Action TU0902. Final Report of COST Action TU0902, Centre for Earth Systems Engineering Research (CESER), Newcastle, UK.

European Factories of the Future Research Association. 2013. "Factories of Future. Multi-Annual Roadmap for the Contractual PPP Under Horizon 2020.” European Commission. www.effra.eu.

Ford, Simon, and Mélanie Despeisse. 2015. “Can Additive Manufacturing Be a Driving 
Force for Sustainable Industrial Systems?” Journal of Cleaner Production Special Vo (AUGUST).

Foresight. 2013. “The Future of Manufacturing: A New Era of Opportunity and Challenge for the UK, Project Report.” The Government Office for Science, London. doi:10.1049/tpe.1971.0034.

Forrester, Jay. 1993. "System Dynamics and the Lessons of 35 Years.” In A SystemsBased Approach to Policy Making, edited by K. B. De Greene, 199-240. Boston, Massachusetts, USA: Springer US. doi:10.1007/978-1-4615-3226-2_7.

Fox, Stephen. 2015. “Moveable Factories: How to Enable Sustainable Widespread Manufacturing by Local People in Regions without Manufacturing Skills and Infrastructure.” Technology in Society 42. Elsevier Ltd: 49-60. doi:10.1016/j.techsoc.2015.03.003.

Frye-Levine, Laura Alex. 2012. “Sustainability Through Design Science: Re-Imagining Option Spaces Beyond Eco-Efficiency.” Sustainable Development 20 (3): 166-79. doi:10.1002/sd.1533.

Grimm, N B, J M Grove, S T a Pickett, and C L Redman. 2008. “Integrated Approaches to Long-Term Studies of Urban Ecological Systems.” BioScience 50 (7): 571-84. Harvey, Charles, and John Press. 1988. "Studies in the Business History of Bristol.” In Bristol Historical Resource, edited by Peter Wardley, David Griffiths, and Keith Ramsey. Bristol Academic Press. http://humanities.uwe.ac.uk/bhr/Main/. Hendriks, Caroline, Richard Obernosterer, Daniel Müller, Susanne Kytzia, Peter Baccini, and Paul H. Brunner. 2000. "Material Flow Analysis: A Tool to Support Environmental Policy Decision Making. Case-Studies on the City of Vienna and the Swiss Lowlands.” Local Environment 5 (3): 311-28. doi:10.1080/13549830050134257. 
Höjer, Mattias, and Josefin Wangel. 2015. “Smart Sustainable Cities: Definition and Challenges.” In ICT Innovations for Sustainability, edited by Lorenz Hilty and B. Aebischer, 333-49. Cham, Switzerland: Springer International Publishing. doi:10.1007/978-3-319-09228-7.

Hosseini, Seyedmohsen, Kash Barker, and Jose E. Ramirez-Marquez. 2016. “A Review of Definitions and Measures of System Resilience.” Reliability Engineering and System Safety 145: 47-61. doi:10.1016/j.ress.2015.08.006.

Huang, Jianhuan, Xiaoguang Yang, Gang Cheng, and Shouyang Wang. 2014. “A Comprehensive Eco-Efficiency Model and Dynamics of Regional Eco-Efficiency in China.” Journal of Cleaner Production 67: 228-38. doi:10.1016/j.jclepro.2013.12.003.

Huang, S. H., Peng Liu, Abhiram Mokasdar, and Liang Hou. 2013. “Additive Manufacturing and Its Societal Impact: A Literature Review.” International Journal of Advanced Manufacturing Technology 67 (5-8): 1191-1203. doi:10.1007/s00170-012-4558-5.

Hutchinson, M. F., S. Dovers, R. Letcher, J. Lindesay, F. P. Mills, and J. Sharples. 2006. “Integrated Assessment of Climate Change Impacts.” Report on Methodology and Workshop held at the Australian National University 3-4 July 2005.

Inostroza, Luis. 2014. “Measuring Urban Ecosystem Functions through ‘Technomass’ A Novel Indicator to Assess Urban Metabolism.” Ecological Indicators 42. Elsevier Ltd: 10-19. doi:10.1016/j.ecolind.2014.02.035.

Kennedy, C., S. Pincetl, and P. Bunje. 2011. "The Study of Urban Metabolism and Its Applications to Urban Planning and Design.” Environmental Pollution 159 (8-9). Elsevier Ltd: 1965-73. doi:10.1016/j.envpol.2010.10.022. 
Kohtala, Cindy. 2015. “Addressing Sustainability in Research on Distributed Production: An Integrated Literature Review.” Journal of Cleaner Production 106. Elsevier Ltd: 654-68. doi:10.1016/j.jclepro.2014.09.039.

Korhonen, Jouni, and Thomas P Seager. 2008. “Beyond Eco-Efficiency: A Resilience Perspective.” Business Strategy and the Environment 17: 411-19. doi:10.1002/bse. Luger, Michael, Jeff Butler, and Graham Winch. 2013. “Infrastructure and Manufacturing: Their Evolving Relationship.” Foresight, Government Office for Science.

Mazzucato, Mariana. 2013. The Entrepreneurial State. Anthem Press.

Mohanty, R P, and S G Deshmukh. 1999. "Evaluating Manufacturing Strategy for a Learning Organization: A Case.” International Journal of Operations \& Production Management 19 (3): 308-28.

Morgan, Julian, and Peter Mitchell. 2015. “Employment and the Circular Economy. Job Creation in a More Resource Efficient Britain.” Green Alliance, London; WRAP, Banbury. doi:10.13140/RG.2.1.1026.5049.

Pahl-Wostl, Claudia. 2004. "Why Do We Need a Society for Integrated Assessment?” The Integrated Assessment Society.

Pearson, Hannah, Glen Noble, and Joshua Hawkins. 2013. “Re-Distributed Manufacturing Workshop Report.” EPSRC.

Rauch, Erwin, Patrick Dallasega, and Dominik T. Matt. 2016. “Sustainable Production in Emerging Markets through Distributed Manufacturing Systems (DMS).” Journal of Cleaner Production 135. Elsevier Ltd: 127-38. doi:10.1016/j.jclepro.2016.06.106.

Rauch, Erwin, Matthias Dallinger, Patrick Dallasega, and Dominik T. Matt. 2015. “Sustainability in Manufacturing through Distributed Manufacturing Systems 
(DMS).” Procedia CIRP 29. Elsevier B.V.: 544-49.

doi:10.1016/j.procir.2015.01.069.

Richardson, G. 2011. "Reflections on the Foundations of System Dynamics.” System Dynamics Review 27 (3): 219-43. doi:10.1002/sdr.

Roland Berger Strategy Consultants. 2011. “Trend Compendium 2030.” www.rolandberger.com/gallery/trendcompendium/tc2030/content/assets/trendcompendium2030.pdf.

Schieritz, Nadine, and A. GroBler. 2003. "Emergent Structures in Supply Chains - a Study Integrating Agent-Based and System Dynamics Modeling.” 36th Annual Hawaii International Conference on System Sciences, 2003, 9-pp. doi:10.1109/HICSS.2003.1174226.

Simmie, James, J. Carpenter, A. Chadwick, and Ron Martin. 2008. “History Matters: Path Dependence and Innovation in British City-Regions.” NESTA, London. www.nesta.org.uk/publications/history-matters.

Simmie, James, and Ron Martin. 2010. “The Economic Resilience of Regions: Towards an Evolutionary Approach.” Cambridge Journal of Regions, Economy and Society 3 (1): 27-43. doi:10.1093/cjres/rsp029.

Spector, J.Michael, Dean L Christensen, Alexei V Sioutine, and Dalton McCormack. 2001. "Models and Simulations for Learning in Complex Domains: Using Causal Loop Diagrams for Assessment and Evaluation.” Computers in Human Behavior 17 (5-6): 517-45. doi:10.1016/S0747-5632(01)00025-5.

Sterman, John. 2000. Business Dynamics: Systems Thinking and Modeling for a Complex World. Boston; London: Irwin/McGraw-Hill.

—. 2001. "System Dynamics Modeling: Tools for Learning in a Complex World.” California Management Review 43 (4). 
Taleb, Nassim Nicholas. 2012. Anti-Fragile: How to Live in a World We Don't Understand, Volume 3. Allen Lane. doi:10.1080/14697688.2013.830860.

The UK Cabinet Office. 2013. “National Risk Register of Civil Emergencies,” 1-58.

Thomas, Andrew, Paul Byard, Mark Francis, Ron Fisher, and Gareth R.T. White. 2016. "Profiling the Resiliency and Sustainability of UK Manufacturing Companies." Journal of Manufacturing Technology Management 27 (1): 82-99. doi:10.1108/JMTM-06-2014-0086.

Ticehurst, Jenifer L., Rebecca A. Letcher, and David Rissik. 2008. “Integration Modelling and Decision Support: A Case Study of the Coastal Lake Assessment and Management (CLAM) Tool.” Mathematics and Computers in Simulation 78 (2-3): 435-49. doi:10.1016/j.matcom.2008.01.024.

Vugrin, Eric D., Drake E. Warren, and Mark A. Ehlen. 2011. “A Resilience Assessment Framework for Infrastructure and Economic Systems: Quantitative and Qualitative Resilience Analysis of Petrochemical Supply Chains to a Hurricane.” Process Safety Progress 30 (3). doi:10.1002/prs.

Zhang, Yan. 2013. "Urban Metabolism: A Review of Research Methodologies.” Environmental Pollution 178. Elsevier Ltd: 463-73. doi:10.1016/j.envpol.2013.03.052. 
Table 1: Steps in the IA (adapted from (Hutchinson et al. 2006))

\begin{tabular}{|l|l|}
\hline \multicolumn{1}{|c|}{ Step } & \multicolumn{1}{c|}{ Purpose } \\
\hline $\begin{array}{l}\text { One - Aims and } \\
\text { Objectives }\end{array}$ & $\begin{array}{l}\text { Identify the aims and objectives of the IA including stakeholders and } \\
\text { potential audiences for the results }\end{array}$ \\
\hline Two - Parameters & $\begin{array}{l}\text { Build an understanding of the constraints, issues, and possible } \\
\text { measures of system performance }\end{array}$ \\
\hline $\begin{array}{l}\text { Three - Conceptual } \\
\text { Framework }\end{array}$ & $\begin{array}{l}\text { Develop an initial conceptual framework, including key drivers, } \\
\text { management and development options, and state and utility variables } \\
\text { and their interactions }\end{array}$ \\
\hline $\begin{array}{l}\text { Four - Stakeholder } \\
\text { Review of } \\
\text { Framework }\end{array}$ & $\begin{array}{l}\text { Workshop the initial conceptual framework and general scenarios with } \\
\text { stakeholders }\end{array}$ \\
\hline $\begin{array}{l}\text { Five - Revised } \\
\text { Framework }\end{array}$ & $\begin{array}{l}\text { Revise the initial framework using stakeholder feedback, producing a } \\
\text { working version of the conceptual framework }\end{array}$ \\
\hline $\begin{array}{l}\text { Six to Eleven - } \\
\text { data population, } \\
\text { stakeholder review } \\
\text { of results, } \\
\text { dissemination }\end{array}$ & $\begin{array}{l}\text { - Identify existing data and information available to populate the } \\
\text { assessment } \\
\text { Identify and fill key knowledge or information gaps } \\
\text { Populate the assessment with data and other information } \\
\text { Review the conceptual framework and assessment model with } \\
\text { stakeholders } \\
\text { Revise the assessment, results and conclusions in the face of } \\
\text { stakeholder feedback } \\
\text { Distribute the assessment to relevant stakeholders or other user } \\
\text { groups with appropriate training or information on its use }\end{array}$ \\
\hline
\end{tabular}

Table 2: Measures of System Performance

\begin{tabular}{|l|l|}
\hline $\begin{array}{c}\text { Measure of } \\
\text { System } \\
\text { Performance }\end{array}$ & \multicolumn{1}{c|}{ Description } \\
\hline $\begin{array}{l}\text { Economic } \\
\text { Sustainability }\end{array}$ & $\begin{array}{l}\text { Income from local taxes and grants from central government are sufficient } \\
\text { to maintain a good quality of civic life, infrastructure, and to support } \\
\text { businesses; citizens can be economically self-reliant; businesses can attract } \\
\text { investment. }\end{array}$ \\
\hline $\begin{array}{l}\text { Environmental } \\
\text { Sustainability }\end{array}$ & $\begin{array}{l}\text { The region's ecosystems are healthy and can remain so into the future; the } \\
\text { city's urban metabolism is low in relation to the prosperity it generates and } \\
\text { compared to other similar cities. }\end{array}$ \\
\hline $\begin{array}{l}\text { Short-term } \\
\text { Resilience }\end{array}$ & $\begin{array}{l}\text { Public and private agencies are able to establish normal services, supply } \\
\text { chains, and economic activity soon after short-term economic, social, } \\
\text { political, or environmental shocks. }\end{array}$ \\
\hline $\begin{array}{l}\text { Long-term } \\
\text { Resilience }\end{array}$ & $\begin{array}{l}\text { The regional economy, infrastructure and society as a whole is able to } \\
\text { evolve and adapt in response to a range of long-term stressors; this } \\
\text { evolution will likely look like 'constant change rather than stability' } \\
\text { (Simmie and Martin 2010). }\end{array}$ \\
\hline
\end{tabular}




\begin{tabular}{|l|l|}
\hline $\begin{array}{c}\text { Measure of } \\
\text { System } \\
\text { Performance }\end{array}$ & \multicolumn{1}{c|}{ Description } \\
\hline $\begin{array}{l}\text { Manufacturing } \\
\text { Sector } \\
\text { Resilience }\end{array}$ & $\begin{array}{l}\text { Local manufacturing sectors are able to utilise changes in regional, national } \\
\text { and international supply chains, technologies, and markets as opportunities } \\
\text { to transform and grow, whilst decreasing environmental impacts and } \\
\text { providing local employment. }\end{array}$ \\
\hline
\end{tabular}

Table 3: Key drivers, management and development options, and state and utility variables

\begin{tabular}{|l|l|}
\hline \multicolumn{1}{|c|}{ Category } & \multicolumn{1}{c|}{ Identified Elements } \\
\hline $\begin{array}{l}\text { Drivers (short } \\
\text { term } \\
\text { disturbances) }\end{array}$ & $\begin{array}{l}\text { Pandemics/changes in workforce; social unrest; changes in availability } \\
\text { and/or cost of materials or parts; technology disruption; economic } \\
\text { downturns/upturns; extreme climatic events; sudden changes in political } \\
\text { landscape; changes in supply chain legislation; changes in business } \\
\text { ownership; shocks that change ethical stances (The UK Cabinet Office } \\
\text { 2013; Avon and Somerset Local Resilience Forum 2011). }\end{array}$ \\
\hline $\begin{array}{l}\text { Drivers (long } \\
\text { term } \\
\text { disturbances) }\end{array}$ & $\begin{array}{l}\text { Availability of investment capital; changing demographics; automation; } \\
\text { globalisation and future markets; scarcity of resources; mass } \\
\text { customisation; dynamic technology and innovation; climate change, } \\
\text { global knowledge society, and the role of global non-governmental } \\
\text { organisations (European Factories of the Future Research Association } \\
\text { 2013; Roland Berger Strategy Consultants 2011). }\end{array}$ \\
\hline $\begin{array}{l}\text { Management and } \\
\text { Development } \\
\text { Options }\end{array}$ & $\begin{array}{l}\text { Workforce skills and education; investment in new manufacturing } \\
\text { technologies/machinery; government support for innovation; investment } \\
\text { in infrastructure; infrastructure to support international trade, e.g. } \\
\text { through on-line trading; environmental laws; environmental standards } \\
\text { for products; new business models for RDM }\end{array}$ \\
\hline $\begin{array}{l}\text { State variables } \\
\text { (indicators, } \\
\text { outputs or goals) } \\
\text { (Ticehurst, } \\
\text { Letcher, and } \\
\text { Rissik 2008) }\end{array}$ & $\begin{array}{l}\text { Volume of production in the area; "local for local” production vs. "local } \\
\text { for global”; levels of employment and equality; urban metabolism } \\
\text { indicators; health of the manufacturing sectors (e.g. how many start-ups, } \\
\text { how long organisations survive); volume of goods consumed and source } \\
\text { of production (place of production, distributed or centralised) }\end{array}$ \\
\hline $\begin{array}{l}\text { Utility variables } \\
\text { (monetary values) }\end{array}$ & $\begin{array}{l}\text { The gross value added (GVA) from manufacturing activities and impact } \\
\text { on employees and city; financial disbenefits and benefits created by } \\
\text { disturbances; general trends in regional prosperity (e.g. average } \\
\text { disposable income); amount of investment in infrastructure and start-ups }\end{array}$ \\
\hline
\end{tabular}


Table 4: Suggested Development of the Strawman Model from the Workshop

Participants, with Responses from the Project Team

\begin{tabular}{|c|c|}
\hline Comments from workshop participants & Reflections from Project Team \\
\hline $\begin{array}{l}\text { Presses and pulses should be split into those } \\
\text { that are positive and provide opportunities } \\
\text { (e.g. mass customisation) and those that are } \\
\text { negative and create stresses (e.g. resource } \\
\text { scarcity). }\end{array}$ & $\begin{array}{l}\text { While most presses are detrimental to a city, } \\
\text { they could prove to be an opportunity; pulses } \\
\text { and presses can be either good or bad } \\
\text { depending on the response of a city, individual } \\
\text { companies, and markets. }\end{array}$ \\
\hline $\begin{array}{l}\text { The model should represent the effect of } \\
\text { presses and pulses differently. Presses lead } \\
\text { to step changes and the transition to a new } \\
\text { system regime; pulses cause temporary } \\
\text { disturbances, with systems eventually } \\
\text { returning to their equilibrium state. }\end{array}$ & $\begin{array}{l}\text { While it is true that the nature of pulses and } \\
\text { presses can create a different response in the } \\
\text { system, presses may stress and weaken a } \\
\text { system over time, meaning that even a small } \\
\text { pulse event can cause a regime change; the } \\
\text { combined effects of the two needs to be } \\
\text { considered. }\end{array}$ \\
\hline $\begin{array}{l}\text { Presses do not really exist for most } \\
\text { organisations. They generally have } \\
\text { insufficient resources or skills to be able to } \\
\text { monitor and respond to presses until the } \\
\text { presses have become a real business } \\
\text { concern for them - at which point the } \\
\text { disturbance looks like a pulse. }\end{array}$ & $\begin{array}{l}\text { This is a valuable insight reflecting real world } \\
\text { experience, but is perhaps more a question of } \\
\text { perspective rather than about the nature of the } \\
\text { disturbances. The definition of the nature of } \\
\text { pulses and presses is that presses are slow } \\
\text { moving and widespread, while pulses last days } \\
\text { or weeks at the most. }\end{array}$ \\
\hline $\begin{array}{l}\text { The city is relatively prosperous compared } \\
\text { to other UK cities, so can be seen as } \\
\text { economically resilient. Its economic } \\
\text { diversity has been important, especially } \\
\text { compared to cities that developed around a } \\
\text { single industry. }\end{array}$ & $\begin{array}{l}\text { Bristol's economic success masks some } \\
\text { underlying social problems including very high } \\
\text { levels of inequality and persistent } \\
\text { unemployment in some wards of the city that } \\
\text { previously housed employees in mass } \\
\text { manufacturing. }\end{array}$ \\
\hline $\begin{array}{l}\text { What is the future of work and what will be } \\
\text { the quality of jobs? New technologies could } \\
\text { create high levels of productivity in some } \\
\text { industries, some new jobs, new skill } \\
\text { requirements, and also job losses due to } \\
\text { automation. }\end{array}$ & $\begin{array}{l}\text { There is growing employment polarisation into } \\
\text { either low skilled/low-paying jobs, or highly } \\
\text { skilled/high-paying jobs (Morgan and Mitchell } \\
\text { 2015). It is unclear whether RDM would help } \\
\text { to ameliorate this polarisation or make it } \\
\text { worse. }\end{array}$ \\
\hline $\begin{array}{l}\text { Time is critical - in terms of survival of } \\
\text { industries, they need to be timely in } \\
\text { responding to global changes in } \\
\text { manufacturing materials and processes. } \\
\text { However, for large engineering companies } \\
\text { existing orders can take years to fill, and so } \\
\text { the overlap between filling orders and } \\
\text { investing in technology innovation needs to } \\
\text { be well managed. }\end{array}$ & $\begin{array}{l}\text { As argued by some, such as (Mazzucato 2013), } \\
\text { publicly funded investment in research and } \\
\text { development is needed to enable } \\
\text { manufacturing companies to succeed in } \\
\text { competitive technology innovation. Public } \\
\text { investment and collaboration with research } \\
\text { organisations (Foresight 2013) can help } \\
\text { companies overcome technology lock-in and } \\
\text { path dependency (Simmie et al. 2008). }\end{array}$ \\
\hline
\end{tabular}




\begin{tabular}{|c|c|}
\hline Comments from workshop participants & Reflections from Project Team \\
\hline $\begin{array}{l}\text { The model needs to reflect the emergent } \\
\text { properties that have been seen in the } \\
\text { manufacturing sector. For example, as } \\
\text { skills develop within certain industries, that } \\
\text { will generate new, innovative businesses as } \\
\text { spin-offs. }\end{array}$ & $\begin{array}{l}\text { Emergence is important (i) within the sector as } \\
\text { new skills and technologies evolve along with } \\
\text { business models, (ii) in relation to } \\
\text { infrastructure as new build can spur } \\
\text { development of new industries (Luger, Butler, } \\
\text { and Winch 2013), (iii) as "related variety" } \\
\text { (Cooke 2012), meaning that local skills can be } \\
\text { transferred from existing industries to new } \\
\text { ones that use similar technologies (e.g. } \\
\text { aerospace to wind turbines) }\end{array}$ \\
\hline $\begin{array}{l}\text { A cultural distance has developed between } \\
\text { society and the physical realities of } \\
\text { manufacturing, since most production is } \\
\text { done out of sight and manufacturing design } \\
\text { is increasingly done in the virtual world, } \\
\text { limiting appreciation for differences } \\
\text { between materials. }\end{array}$ & $\begin{array}{l}\text { There is, theoretically, a causal link between } \\
\text { local making and sustainability, but in which } \\
\text { direction? A well-regulated local making } \\
\text { sector is needed; however, the more distributed } \\
\text { making is, the more difficult to regulate } \\
\text { secondary impacts such as waste and } \\
\text { emissions. }\end{array}$ \\
\hline $\begin{array}{l}\text { The desire to increase prosperity } \\
\text { encourages the reinforcing of "local for } \\
\text { global” innovation (goods made locally and } \\
\text { sold elsewhere around the world). } \\
\text { The desire to sustain manufacturing in the } \\
\text { face of strong presses requires "local for } \\
\text { local" innovation (goods made and sold } \\
\text { locally). }\end{array}$ & $\begin{array}{l}\text { This links the different aspects of resilience - } \\
\text { in being more economically resilient and } \\
\text { viable through exports of products (e.g. } \\
\text { aerospace industry); and in being resilient } \\
\text { against supply chain disruptions through more } \\
\text { local production. }\end{array}$ \\
\hline $\begin{array}{l}\text { Participants found it difficult to verify } \\
\text { several of the causal links in the strawman } \\
\text { model, in terms of direction of causation. } \\
\text { The link between economic sustainability } \\
\text { and environmental sustainability was most } \\
\text { commented on. }\end{array}$ & $\begin{array}{l}\text { This indicates that the strawman model lacked } \\
\text { sufficient detail. The measure of sustainability } \\
\text { is also important - if embodied impacts in } \\
\text { imported products are accounted for then an } \\
\text { increase in local manufacturing could decrease } \\
\text { overall impacts. }\end{array}$ \\
\hline
\end{tabular}


Figure 1: Conceptual framework for exploring the impact of disturbances on the cityregion and its manufacturing sector

Figure 2: "Strawman” Causal Loop Diagram representing an initial theory about the causal relationships between different types of resilience and sustainability and the manufacturing sectors, as presented to workshop participants. Positive causation is represented by arrows with a “+” sign, and negative causation is represented by arrows with a “-“ sign. Balancing (i.e. goal seeking) loops are named B1, B2, etc. and reinforcing (i.e. growth) loops are named R1, R2, etc.

Figure 3: Conceptual Framework further developed as a system dynamics stock and flow model, which represents interactions between economy, infrastructure, the manufacturing sector, and impacts from a variety of different types of disturbances. Boxes represent stocks, or accumulations of things. Stock size rises or falls over time depending on the relative levels of flows into the stock and out from the stock. 